Acta Universitatis Wratislaviensis • No 4046

Literatura i Kultura Popularna XXVI, Wrocław 2020

https://doi.org/10.19195/0867-7441.26.26

Radosław Sztyber

ORCID: 0000-0003-2955-1597

Uniwersytet Zielonogórski

\title{
W stronę megalomanii narodowej na kanwie tetralogii Jacka Komudy pod tytułem Samozwaniec (glosa i kilka uwag na marginesach powieści)
}

Słowa kluczowe: Jacek Komuda, powieść historyczna, Wojciech Dembołęcki, megalomania narodowa, Samozwaniec

Keywords: Jacek Komuda, historical novel, Wojciech Dembołęcki, national megalomania, Samozwaniec [False Dmitry]

Jacek Komuda od około dwóch dziesięcioleci swoją prozą systematycznie i coraz wyraźniej wpisuje się w pejzaż polskiej literatury. Poczytności dokonań autora zaświadczają informacje zawarte choćby na stronie wydawnictwa, z którym się związał. Nakłady poszczególnych tytułów jego pióra osiągnęły ogółem pół miliona egzemplarzy, co wypada uznać za sukces - w warunkach rodzimych - i zarazem oczywisty wykładnik popularności. Są inne czynniki tej wciąż rozwijającej się kariery, aczkolwiek je pominiemy, by skupić się na warsztacie pisarza, przy czym - uściślijmy — chodzi o kwerendę, rozeznanie w przeszłości, jej kolorycie, faktach dziejowych itp., ponieważ to na takim właśnie tle rozgrywa się akcja powieści czy opowiadań Komudy. Orientacja w tym zakresie nie tylko okazuje się korzystna, ale i niezbędna w pisarstwie zakotwiczonym historycznie, a objawia się rozmaicie — przez stylizację językową, rekonstrukcję minionych zdarzeń, ukazywanie temperamentów, zwyczajów (ubioru, upodobań kulinarnych), postaci bądź ich charakterystycznych dla epoki typów itp. Każde rozstrzygnięcie, jak wiadomo, następuje na różnym poziomie szczegółowości i zgodnie z profilem, podejściem do branej pod uwagę przez piszącego materii. 
Jak sugeruje wypowiedź inicjalna szkicu, dotyczy on jedynie drobiazgu — nawet raczej nie dygresji, lecz mimowolnych niejako wtrąceń wplątanych jakby przygodnie w dialog. Mogą one ujść uwadze czytelnika z powodu ich znikomości i... niedorzeczności, zwłaszcza że w jednym przypadku ważne tu słowa wypowiedział bohater, „sięgając po nowy bukłak z gorzałką" ${ }^{1}$, co dość jednoznacznie kwalifikuje wartość obwieszczonej opinii. Jednakże w obu razach wygłasza je - dodajmy gwoli ścisłości — Jacek Dydyński, „Jacek nad Jackami”"; chciałoby się rzec — Polak nad Polakami, sarmata nad sarmatami, a nawet więcej - Scyta nad Scytami... Przecież detale tego typu — autentyczne błahostki w toku czterotomowej narracji, nasyconej zwrotami akcji, wydarzeniami dramatycznymi, okrutnymi — stanowią jednak integralny element cyklu, konstytuują jego kontekst, wreszcie — znakomicie odtwarzają fenomen sarmackości w całej krasie. Zarazem korespondują, jakże ironicznie, z określeniem serii Samozwańca (i niejako rykoszetem nawiązują do jednego z wyimków przytoczonych niżej z siedemnastowiecznego traktatu): „Orły na Kremlu”, zdobytym i niebawem utraconym. I takie to orły, jak i ten jeden - pozwólmy sobie na kolokwialne sformułowanie - co w tytulaturze anonsowany był carem Rosji, a właściwie nigdy nie dostąpił zaszczytu okrycia głowy Czapką Monomacha ${ }^{3}$. Ale, złośliwości ciąg dalszy, to nie Polak z krwi i kości, wszak potomek „kukły sztywnej”4 , „maszkary hiszpańskiej” przybyłej ze Szwe$\mathrm{cji}^{5}$ na tronie Rzeczypospolitej. Mowa o Władysławie IV Wazie, królu polskim z woli szlachty i wskutek prawa do wolnej elekcji. Leszek Podhorodecki przebieg tej akcji politycznej, a zwłaszcza jej finał kwitował wymownie, adekwatnie do spraw tytułując stosowny rozdział monografii: Marzenia o carskiej koronie ${ }^{6}$. Niespełnione marzenia oczywiście. Mrzonki zatem. Nadto, dodajmy, podnoszone i nadal niedookreślone niuanse $\mathrm{w}$ żaden sposób nie wpływają na tok fabularny.

Pole namysłu trzeba jeszcze rozszerzyć o treść przypisów, jakimi autor dopełnia zasadniczy tekst snutej opowieści. Wydają się one poniekąd spójną częścią cyklu, zawierają bowiem między innymi objaśnienia leksykalne, dopełniają niektóre wątki bądź też wskazują źródła, jakie legły u podstaw tej czy innej wypowiedzi. Inne odznaczają się metatekstowością, kolejne są rodzajem samooceny wybranych posunięć pióra prozaika. Wszystkie w pewien sposób uprawdopodobniają roztaczany przed czytelnikiem fikcyjny obraz świata przedstawionego, mimo iż w kilku z nich znajdziemy pomysły zgoła... nieprawdopodobne ze względu na ich fantastyczną wymowę lub brak chronologicznego uzasadnienia. Wszelako trud-

1 J. Komuda, Samozwaniec, t. 3, Lublin 2013, s. 19.

2 Cyt. za: A. Kobus, Sarmatotopie. Formacja sarmacka w twórczości Jacka Komudy, „Teksty Drugie" 2015, nr 1, s. 283.

3 Zob. H. Wisner, Władystaw IV Waza, Wrocław 2009, s. 11-19. „Miejsce Zygmunta III zajął Władysław IV [...] obrany wielki car moskiewski” (ibidem, s. 64). Zob. też idem, Zygmunt III Waza, Warszawa 1984, s. 60-73.

${ }^{4}$ H. Wisner, Wtadystaw IV Waza..., s. 184.

5 J. Ekes, Ztota demokracja, Warszawa 2010, s. 250.

6 Por. L. Podhorodecki, Wazowie w Polsce, Warszawa 1985, s. 121-146. 
no czynić z tej obserwacji fundament jakichkolwiek zarzutów, skoro obcujemy $\mathrm{z}$ utworem literackim, a nie naukowym. Aczkolwiek istnieje dla nich odmienne uzasadnienie, mianowicie gdy weźmiemy pod rozwagę autorską wolę oddania ducha, klimatu epoki, nie odgrywają one roli wyłącznie atrakcyjnego (dzięki swojej oryginalności) ornamentu, ponieważ są ważnym budulcem w procesie odtwarzania mentalności ówczesnych ludzi, tak jak wspominane wcześniej detale, które w odczuciu samego Jacka Komudy domagały się po prostu komentarza. W efekcie może to być odpowiednik marginaliów, częstokroć spotykanych w ojczystych starych drukach. Nieregularne te przypisy — redagowane według niezdefiniowanych kryteriów (może nawet spontanicznie), raczej wedle uznania autora (co równocześnie niezbicie dowodzi jego i fascynacji tematyką, i upodobań lekturowych) - wolno traktować jako bibliograficzne zaplecze tetralogii, wprawdzie niekompletne, gotowe wszakże do użytku dla zainteresowanego nią czytelnika.

Czas przedstawić anonsowane detale. Wiążą się one przede wszystkim z księdzem Wojciechem Dembołęckim ${ }^{7}$ i co najmniej dwoma jego dziełami: z 1623 i 1633 roku. Już w Opowieściach z Dzikich Pól niezwykła sylwetka franciszkanina pojawiła się we wstępnej partii zbioru. Oddajmy głos bohaterowi utworu, Serafinowi Muraszce: „toż przecież kompan mój od kielicha, uczony kaznodzieja Wojciech Dębołęcki"8 — to krótki i wymowny rys krnąbrnego mnicha, choć przytoczono tu niepełne zdanie, które wypadnie skończyć nieco niżej, zapowiadając kolejny i najważniejszy dla tej glosy kontekst Samozwańca. Siedemnastowieczna postać przyciągała uwagę zresztą od dawna - wcale celnej charakterystyki powieściowej Dembołęckiego dokonał w ubiegłym stuleciu Bohdan Królikowski w książce o lisowczykach. Jeden z głównych jej protagonistów, Mateusz, myślą bardzo chętnie wracał właśnie „do księdza Dembołęckiego, kapelana elearów z papieskiego przykazania, jak sam prawił, nie mając na to pisanego testimonium". A ciekawie utrwaliła się w pamięci tego bohatera powieściowego „cudaczna postać” wojskowego duszpasterza:

rechotano po chorągwiach, kiedy człapał na wielkiej kobyle, chudy, z kozią bródką, kapturem wiejącym na plecach, z połami habitu zadartymi dla wygodniejszej jazdy, podwiązanymi franciszkańskim sznurem. Gadał dużo, nie zawżdy do sensu. Kazania miał osobliwe, na których — bywało — boki zrywano od śmiechu. Co nabożniejsi gorszyli się, ruszając ramionami na takowego kapelana, któren faramuszki opowiada na egzortach, niby facecje w karczmie. Baranków swoich, niebożęta - jak mianował elearów — nazywał Machabeuszami walczącymi ze smokiem herezji, to znów Dawidami biorącymi za procę przeciwko Filistyńczykom obmierzłym. Prawił takoż, co sam Bóg zaciągał lisowskie bractwo na cesarską służbę dla po-

${ }^{7}$ Nazwisko, wskazujące jedną osobę, przetrwało w wielu odmiankach. Zob. Bibliografia literatury polskiej „Nowy Korbut”, t. 2. Piśmiennictwo staropolskie (hasta osobowe A-M), oprac. zespół pod kier. R. Pollaka, Warszawa 1964, s. 123. Zachowujemy jego pisownię w przywoływanych cytatach w tekście głównym — Dembołęcki, „tak się albowiem pisał” (J. Bartoszewicz, Ksiądz Wojciech z Konojad Dembołęcki, [w:] idem, Studia historyczne i literackie, wyd. K. Bartoszewicz, t. 2, Kraków 1881, s. 92).

8 J. Komuda, Opowieści z Dzikich Pól, Warszawa 1999, s. 11. 
hańbienia plugawego luterstwa. Gardło przepaściste, nos tęgi: zawżdy wino wywęszy! Niech no tylko siędzie kompania w loszku przy gąsiorku reńskiego, już i ksiądz u stoła. Lano mu do kielicha, bo mówił ucieszne wielce rzeczy, aleć i ciekawe?

Marna to poniekąd reputacja, zwłaszcza że ukazuje duchownego nie tylko nieunikającego trunków, ale nadzwyczaj chętnie pełniącego toasty. A więc posunięcie Jacka Komudy dziwić nie może, by przywołać imię i nazwisko zakonnego brata w zbliżonej sytuacji — suto zakrapianej akwawitą biesiady akurat. Autor współczesnego cyklu o pierwszej dymitriadzie również pokusił się o przypomnienie (w obrębie przypisów) zmarłego blisko czterysta lat temu ideologa sarmackiego; pisał o nim między innymi:

postać niepospolita i zgoła wymykająca się wszelakim regułom. [...] również w życiu prywatnym był osobowością zgoła nietuzinkową i jako żołnierz-mnich prowadził wesoły tryb życia, nie stroniąc od trunków oraz panien łatwego i lekkiego autoramentu. Jako członek towarzystwa powołanego w celu wykupywania jeńców od Turków zdefraudował - prawdopodobnie przepił, przehulał, przejadł [...] — pieniądze przeznaczone na uwolnienie więźniów z pohańskiej niewoli ${ }^{10}$.

W rezultacie portretowanego księdza niewątpliwie widzimy w jaskrawych barwach, malujących człowieka nieprzeciętnego, którego ścieżki żywota wielokrotnie ocierały się o zwyczajny skandal różnej natury. W ujęciu tym, rzecz jasna, niebagatelną kwestią jest ambiwalencja postawy franciszkanina, gwiżdżącego na klasztorne rygory, przy czym jego epoka aż kipi od przykładów poetyckich konceptów łączących ogień z wodą, co znalazło także odbicie w licznych ówczesnych życiorysach. Przypomniane fakty są świetnie znane, udokumentowane i dostatecznie ukazane w literaturze fachowej, nadto — jak widać — Komudę uprzedził choćby prozaik urodzony w pierwszej połowie ubiegłego wieku. Do sformułowania tej refleksji skłaniają twórcze i warsztatowe deklaracje samego sprawcy opublikowanej w tym milenium powieści.

Najlepszym źródłem są jednak księgi sądowe, one nie przekłamują historii. Oczywiście są nieraz przejaskrawione, jeśli chodzi o rezultaty starć, procesów, grabieży. Każdy szlachcic, któremu zrąbano brzozę w lesie, pisał zaraz, że wycięto mu tysiąc drzew, każdy warchoł po zwadzie czy pojedynku, którego był sprawcą, pędził do grodu, aby przedstawić siebie jako ofiarę. Jednak opisy ludzkich namiętności, postaw, charakterów są jak najbardziej autentyczne. To materiał, na podstawie którego można stworzyć piękną wizję XVII wieku, znacznie ciekawszą i prawdziwszą w porównaniu do tej, którą przedstawiał Sienkiewicz ${ }^{11}$.

Rywalizacja z noblistą może wydać się ryzykowna, niemniej z pewnością przydaje samozwańczemu konkurentowi splendoru. Zarazem warto zauważyć, że i Henryk Sienkiewicz nie zamykał oczu na zjawiska patologiczne, a ich uosobieniem mogą być wzmianki w Ogniem i mieczem o głośnym Samuelu Łaszczu

9 B. Królikowski, Szable nie rdzewiaty, czyli przewagi lisowczyków nad Turkiem srogim pod Cecora i Chocimiem czynione, Warszawa 1983, s. 310.

10 J. Komuda, Samozwaniec..., s. 337-338.

11 Cyt. za: A. Kobus, op. cit., s. 279. 
(celowo pomijamy przykład Andrzeja Kmicica z Potopu). Indywiduum to znane jest zwłaszcza ze swoich „osiągów” na salach sądowych — razem, gdy umierał, „za różne ekscesa [...] miał na sobie 236 banicyj i 37 infamii”"12. Podszywał nimi ponoć swoją „ferezyję" i dlatego zwano go „wyjątkowym praw poniewiercą"13. Słynął z bitności, zaangażowania w sprawy wojenne, o czym długo by pisać ${ }^{14}$, lecz także inną jego biegłość podsumowano symptomatycznie: „ostrych dowcipów gębacz” ${ }^{15}$. „Łaszcz drwił ze wszystkich i ze wszystkiego, lekceważył zarówno rzeczy ludzkie i boskie, tak samo urągał prawu i nie szanował religii, słowa jego zaprawdę szyderstwem były opaczne i przeczyły postępkom"16. Sienkiewicz jędrnie, dosadnie i w sposób skondensowany charakteryzował tę barwną postać:

Pan Łaszcz bowiem, choć rycerz straszliwy, dla pogaństwa jak mało kto groźny, był zarazem przesławnym hulaką, ucztownikiem, kosterą, któren czas od bitew, modlitew, zajazdów i zabijatyk wolny lubił nade wszystko spędzać w kole takich ludzi jak pan Zagłoba, pić na umór i krotofil słuchać. Był to warchoł na wielką rękę, który sam jeden tyle wzniecał niepokoju, tyle razy przeciw prawu wykroczył, że w każdym innym państwie byłby dawno głową nałożył. Ciążyła też na nim niejedna kondemnata, ale on nawet w czasie pokoju niewiele sobie $\mathrm{z}$ nich robił, a teraz w czasie wojny tym bardziej wszystko poszło w zapomnienie. [...] od chwili odpoczynku w Zbarażu stał się prawie nieznośny przez hałasy, które wzniecał. Swoją drogą nikt by nie zliczył i nie spisał, ile pan Zagłoba wina u niego wypił, ile się nagadał i naopowiadał z wielką gospodarza uciechą, któren też go codziennie zapraszał ${ }^{17}$.

Słowem, zestawianie arcydzieła powieściopisarskiego końca XIX wieku z omawianą właśnie książką, choć zasadne, musi być obwarowane wieloma obostrzeniami, uwzględniającymi czas powstania, cel czy zewnętrzne okoliczności ${ }^{18}$. Równocześnie wolno powiedzieć, że sploty fabularne, perypetie bohaterów porównywanych tekstów wykazują sporo zbliżeń — co innego zaś punkty dojścia, bo różne przecież były i intencje. Niewyłącznie zaciekawiać pragnął Sienkiewicz, lecz nade wszystko budzić narodowego ducha; innym zamierzeniom — nie zawsze spójnym - hołduje dzisiejszy twórca. W efekcie różny jest rozkład akcentów. Zagadnienie w wielu aspektach przekonująco prezentuje studium Aldony Kobus ${ }^{19}$. Natomiast językoznawcze badanie komparatystyczne, zestawiające

12 A. Weryha Darowski, Samuel Łaszcz. Strażnik koronny, Kijów 1865, s. 17.

13 Por. ibidem, s. 28.

14 Por. ibidem, passim. Jeden wypis: „w całym pochodzie Łaszcz zawsze był na przedzie, tu czatę rozgromił, tam napłoszył i urwał jaką kupę kozacką; na dobry dzień hetmanowi przesyła zachwyconych [to jest pojmanych - R.S.] języków i znów się sam jawi z ustną relacyją o nieprzyjacielu" (ibidem, s. 10).

15 Ibidem, s. 27.

16 Ibidem.

17 H. Sienkiewicz, Ogniem i mieczem. Powieść z lat dawnych, t. 2, Lwów 1931, s. 34.

18 Zob. T. Bujnicki, Jacek Komuda w kręgu aluzji sienkiewiczowskich, [w:] Pejzaże humanistyczne. Księga jubileuszowa Profesorowi Bolesławowi Faronowi poświęcona, red. A. Ogonowska, Kraków 2017, s. 322.

19 Zob. A. Kobus, op. cit., s. 278-293. Zob. też T. Bujnicki, op. cit., passim. 
Bohuna Komudy i Trylogię, ujawnia daleko idącą zależność obecnie wciąż aktywnego pisarza od swojego wielkiego poprzednika ${ }^{20}$.

Wróćmy jednak do Dembołęckiego. Komuda w stosownym przypisie ${ }^{21}$ przytacza spory fragment autentycznego dokumentu, będącego świadectwem nieomal natychmiastowej (sformułowanej w 1634 roku) reakcji konfratrów zakonnych na ogłoszenie drukiem kuriozalnego Wywodu jedynowłasnego państwa świata (Warszawa 1633) - rzecz jasna, to pogrążająca autora i bezwzględnie miażdżąca ocena traktatu określonego w tym wypisie mało kurtuazyjnie jako zwyczajne „głupstwo". Decyzja powieściopisarza jest zrozumiała, bo i siedemnastowieczna nota efektownie ujęta, niemniej i ona od lat funkcjonuje w ramach literatury przedmiotowej poświęconej księdzu Wojciechowi. Z dawnych archiwów wydobył ją Julian Bartoszewicz w XIX wieku ${ }^{22}$, a powtórzyli Zygmunt Gloger ${ }^{23}$ oraz Maria Kochańska ${ }^{24}$, by poprzestać tylko na nazwiskach tych trojga badaczy, którzy włączyli ten ekscerpt w tok własnych rozważań. A zatem to nie efekt samodzielnych i żmudnych kwerend Komudy i tym samym żadna rewelacja (w sensie odkrycie), lecz po prostu repeta. Na inne tropy zadłużeń wskazuje ponadto Aldona Kobus $^{25}$, z kolejnymi zdradza się, choć może lepiej powiedzieć — nie kryje, sam twórca-sarmata, jeszcze inne (bo inaczej być nie może) są tożsame z zapleczem źródłowym Trylogii ${ }^{26}$, a „Opowieści z Dzikich Pól [...] wykazują fascynację prozą sienkiewiczowską"27. Tadeusz Bujnicki dookreśla rzecz dosadniej i zaznacza „dominację Sienkiewicza” w prozie Komudy ${ }^{28}$.

Ważniejsze wszakże są tu przesłanki, jakimi kierował się autor Samozwańca w doborze wydobywanych i ostatecznie wykorzystanych w swoim cyklu treści. Znawczyni wyprowadza wniosek w tej materii znamienny: „obraz sarmatyzmu samowoli i bezprawia - Komuda przedstawia jako złoty okres polskiej historii i kultury oraz ideał polskości, który należy propagować także współcześnie"29. Trochę to paradoksalna konstatacja, ale paradoksów można się dopatrzyć więcej i w innej płaszczyźnie; mianowicie lekturze całości niezwykle często towarzy-

20 Zob. D. Szagun, Przekorne nawiązania do Sienkiewiczowskiego wzorca powieści historycznej w „Bohunie” Jacka Komudy, „Acta Universitatis Lodziensis. Folia Linguistica” 2015, nr 49, s. 81-89; T. Bujnicki, op. cit., 327-330.

21 Por. J. Komuda, Samozwaniec..., s. 338.

22 Zob. J. Bartoszewicz, op. cit., s. 104-105.

23 Zob. Z. Gloger, Encyklopedia staropolska ilustrowana, t. 1, Warszawa 1900, s. 313-314.

24 Zob. M. Kochańska, Ksiądz Wojciech Dembołęcki z Konojad, „Prace Literackie” 1, 1956, seria A, nr 2, s. 129.

25 Zob. A. Kobus, op. cit., s. 284.

26 Zob. D. Szagun, op. cit., s. 82, 84, 88-89.

27 A. Kliszcz, Sarmacki zwrot kulturowy?, „Perspektywy Kultury” 2012, nr 6, s. 56.

28 Por. T. Bujnicki, op. cit., s. 322.

29 A. Kobus, op. cit., s. 284. Zasadniczo inaczej kwestia ta wypada w świetle słów zawartych w serwisie internetowym Fabryki Słów, gdzie czytamy między innymi, że Komuda — ,inaczej niż Sienkiewicz — woli pisać ku przestrodze niż ku pokrzepieniu serc" (https://fabrykaslow.com.pl/ autorzy/jacek-komuda/, dostęp: 7.02.2019). 
szy szczęk szabel, świst kul armatnich czy samopałów, słychać odgłosy pijatyk, burd, jęk torturowanych, brzęk kajdan, krępujących ruchy więźniów, co mogłoby wskazywać, że pisarz znajdzie sporo inspiracji w innej książce Dembołęckiego, mianowicie w Przewagach elearów polskich, co ich niegdy lisowczykami zwano (Poznań 1623) - jednym z pamiętników batalistycznych XVII wieku, jak definiował tę relację, obok podobnych świadectw piśmienniczych, Marcin Bauer ${ }^{30}$.

Zabytek ten stanowi najobszerniejsze źródło wiedzy na temat lisowczyków, dodatkowo najemniczy pułk zawiązał się właśnie w okresie zawieruchy wywołanej przez siły przychylne dwóm Łżedymitrom ${ }^{31}$, co aż nadto przekonuje o zasadności sięgnięcia po ten tytuł, jedno $\mathrm{z}$ oryginalniejszych $\mathrm{w}$ naszych dziejach wspomnień osobistych ${ }^{32}$. I nie zabrakło go w przypisie ${ }^{33}$, w którym Komuda zaanonsował go następująco: „, innych dzieł Dembołęckiego wymienić warto”... A więc jednak Przewagi zostały wyłączone $\mathrm{z}$ kanonu branych pod uwagę tekstów z przeszłości, a informacja o nich jawi się jako ciekawostka bądź w najlepszym razie dopełnienie sylwetki kapelana wojskowego i jego dorobku. Dalej czytamy, iż to „wojenna opowieść o lisowczykach, a nade wszystko o ich gwałtach i grabieżach"34. Wyjątkowo ten lakoniczny sąd wypada... niezwykle myląco, gdyby choć odwołać się do cytowanego już wypisu z książki Królikowskiego, który trafnie odczytał wymowę starodruku.

Wydany w Poznaniu pisarski debiut duchownego, jeśli nie jest przykładem czystej apoteozy, to z pewnością apologią kondotierskiego oddziału. Z taką myślą powstało sprawozdanie, by — doprecyzujmy — odbudować dobre imię skompromitowanej formacji zbrojnej i zapobiec obłożeniu jej członków infamią. Sprawa, jak wiadomo, przepadła i zakończyła się fiaskiem. Realizacji tego zadania miała służyć widoczna na pierwszy rzut oka transformacja nomenklaturowa, ponieważ najemnicy nieprzypadkowo zostali przeistoczeni w elearów, co (jedynie na papierze) winno oznaczać odnowę moralną; to z tego powodu obdarzony ponadprzeciętną fantazją Dembołęcki insynuował, że wojsko otrzymało nowego wodza i „przekonująco” uzasadniał ich nową nazwę na podstawie swoistej tradycji nazewniczej obowiązującej w pułku. Zwali się wcześniej lisowczykami od nazwiska Aleksandra Józefa Lisowskiego, niemniej w obliczu nowych okoliczności (i już po śmierci twórcy zbieranej kompanii) w rachubę wchodziło miano innego hetmana - rzekomo Boga, któremu cześć oddawano z użyciem między innymi imienia Elohym, stąd... elearowie (nie tylko stąd zresztą). Poza tym franciszkanin wylał sporo atramentu, żeby zatuszować wspomniane przez Komudę „gwałty i grabieże" oraz inne przewinienia, w tym ewidentne dowody niesubordynacji,

30 Por. M. Bauer, Z dziejów batalistyki polskiej. Studia nad pamiętnikami wojennymi z XVII w., Kraków 2007.

31 Por. H. Wisner, Lisowczycy, Warszawa 1995, s. 28-40.

32 Por. K. Jurewicz, Wojciech Dębołęcki i jego ,,Wywód...”, „Terminus” 2007, z. 1 (16), s. 279.

33 J. Komuda, Samozwaniec..., s. 338-339.

34 Ibidem, s. 339. 
zręcznie przekuwane niekiedy w świadectwa męstwa, skutecznej taktyki wojennej itp. Co ciekawe, głucho w książce z 1623 roku o klęsce cecorskiej — lecz to logiczne, skoro autor Przewag programowo gloryfikował tytułowych bohaterów własnej deskrypcji, dlatego dyplomatycznie przemilczał tę sromotną, wstydliwą porażkę 35 (trafiły się niedociągnięcia, wynikłe z pośpiechu, wyziera z nich prawdziwe oblicze lisowczyków, niepochlebne, wbrew zamiarom piszącego tę relację). Niech zwieńczeniem tego akapitu będzie jakże zasadne stwierdzenie Jana Stanisława Bystronia wydobyte ze znanej rozprawy Megalomania narodowa: „przecież nawet grabieżcze wyprawy lisowczyków oddał Dębołęcki pod bezpośrednie kierownictwo Boga" ${ }^{\text {36 }}$. Z jakich powodów Komuda obstaje przy innym stanowisku, nietrudno dociec.

Swobodna organizacja ostatniego segmentu półtorastronicowego przypisu również wprowadza w błąd, człon ten wypełnia bowiem passus: „„Wyście Lutrom do nieba porobili mosty, / Obudziwszy pokutę i wskrzesiwszy posty « — pisał Dembołęcki, radując się z wojennych dzieł elearów"37, jak czytamy w książce z 2013 roku; kompozycja dopowiedzenia zaś równocześnie wskazuje, skąd Komuda zaczerpnął ów wypis - z Przewag, domyśla się czytelnik na podstawie toku myśli zawartej w akapicie. Niemniej mylą się i komentator, i lektor, gdyż dwuwers, bo w istocie to wierszowany i zrymowany dystych, pochodzi z poematu przyznawanego księdzu Wojciechowi, zatytułowanego Żywot kozaków lisowskich, wznowionego niedawno przez Romana Krzywego, choć z inną atrybucją (ten znakomity utwór miałby być efektem wcześnie objawionego talentu Józefa Bartłomieja Zimorowica) oraz polemiką w tej materii ${ }^{38}$, a trzeba dodać, że broszura ukazała się w roku 1620. Czy zatem w tym stanie rzeczy autor Samozwańca i historyk w jednej osobie rzeczywiście wpisuje się w proces wskrzeszania „dawnych obyczajów, postaci, zapomnianych miejsc"? ${ }^{39}$

Tematycznie i chronologicznie Przewagi zbliżają się do tkanki Samozwań$c a^{40}$, aczkolwiek to Wywód znalazł większe uznanie w oczach sprawcy tetralogii z przełomu pierwszej i drugiej dekady XXI wieku. Stąd niejakie wątpliwości — ze względu na czas biegu fabularnego Samozwańca i tłoczenia ,sennika polityczne-

35 Por. R. Sztyber, Wstęp, [w:] W. Dembołęcki, Przewagi elearów polskich, wstęp i oprac. R. Sztyber, Torun 2005, s. 5-146.

36 J.S. Bystroń, Megalomania narodowa, [w:] Jan Stanisław Bystroń. Tematy, które mi odradzano, oprac. i wstęp L. Stomma, Warszawa 1980, s. 298.

37 J. Komuda, Samozwaniec..., s. 339.

38 Por. Józef Bartłomiej Zimorowic. Utwory młodzieńcze, oprac. R. Krzywy, Warszawa 2016, wersety $35-35$, s. 63.

39 Cyt. za: https://fabrykaslow.com.pl/autorzy/jacek-komuda/ (dostęp: 7.02.2019).

40 Przewagi — warto dodać — w wieku, gdy powstawała Trylogia, wznawiano „dla pokrzepienia serc" kilkakrotnie. Por. R. Sztyber, op. cit., s. 134-142. Nadto ich bohaterom tytułowym poświęcono obszerną monografię historyczną — zob. M. Dzieduszycki, Krótki rys dziejów i spraw lisowczyków, t. 1-2, Lwów 1843-1844. 
go" (jak o traktacie wyraziły się Jadwiga Sokołowska i Kazimiera Żukowska ${ }^{41}$ ) — przywiodły Komudę do autorefleksji, że podniesione w powieści „argumenty [...] są pewnym anachronizmem"42. Wypada wreszcie dopowiedzieć przerwane wcześniej zdanie; raz jeszcze oddajmy głos Muraszce: ,uczony kaznodzieja Wojciech Dębołęcki mówił, że i w niebie po polsku mówią, a sam Adam był przecie Polakiem" (Opowieści z Dzikich Pól) ${ }^{43}$. Ta wyrazista aluzja, wywołująca kontekst megalomańskiego traktatu z 1633 roku — ,jednego z manifestów siedemnastowiecznego sarmatyzmu", jak określał to dzieło Marcin Bauer w ślad za Tadeuszem Ulewiczem ${ }^{44}$ - i osadzona w ramach literackiej fikcji, bynajmniej nie jest pierwsza, a tym samym nie jest bezprecedensowa, jak być może życzyłby sobie Komuda. Już w roku 1866 bohater humoreski Obiadowa godzina Władysława Sabowskiego ${ }^{45}$ w myśli wypowiadał bowiem zbliżone słowa: „ksiądz Wojciech z Konojad Dębołęcki dowiódł, że Adam był Polakiem i tak było niezawodnie" 46 . Rzecz jasna, w naukowym dyskursie specjalistycznym aż roi się od tego rodzaju stwierdzeń, uwypuklających niedorzeczność teorii siedemnastowiecznego rywala między innymi Johannesa Goropiusa Becanusa, utrzymującego z kolei, że to w jego wernakularnym języku porozumiewano się w raju ${ }^{47}$. Już w XVII wieku w pisanym mową wiązaną literackim żarcie „wywodowe” rojenia, wyśmiewając je, eksploatował Andrzej Wiszowaty ${ }^{48}$, który tym samym znacząco uprzedził Komudę.

Traktat zagościł na kartach Samozwańca co najmniej dwukrotnie — pierwszy raz autor nie uznał za stosowne, by pochodzenie osobliwych sformułowań udokumentować (być może dlatego, że padło nazwisko franciszkanina), w drugim przypadku pojawiła się przypisowa notatka, którą dość szczegółowo właśnie omó-

41 Poeci polskiego baroku, wstęp, wyb. i oprac. J. Sokołowska, K. Żukowska, t. 1, Warszawa 1977, s. 957.

42 J. Komuda, Samozwaniec..., s. 337.

43 J. Komuda, Opowieści..., s. 11.

44 M. Bauer, Nad „Przewagami elearów polskich” Wojciecha Dembotęckiego. O apologetycznym pamiętniku z walk lisowczyków w krajach monarchii habsburskiej podczas pierwszych lat wojny trzydziestoletniej, „Napis” 11, 2005, s. 62, przyp. 33.

45 Utwór ukazał się w odcinkach. Zob. „Przegląd Tygodniowy Życia Społecznego, Literatury i Sztuk Pięknych" 1866, nr 12, s. 92; nr 13, s. 101; nr 14, s. 108-109; nr 15, s. 116-117.

46 Ibidem, nr 14, s. 109. Ten trop bibliograficzny ustaliła Aneta Narolska, której piszący te słowa serdecznie dziękuje za podzielenie się informacją o znalezisku. Badaczka omawia Obiadowa godzinę wieloaspektowo w studium mającym wejść w postaci odrębnego rozdziału do monografii poświęconej małym formom prozatorskim Sabowskiego. Inna rzecz, że autorka wskazuje na kolejne zadłużenia Komudy w rozprawie Upraszczanie Hugo. „Katedra Marii Panny w Paryżu” w „Diable w kamieniu” Jacka Komudy, [w druku].

47 Zob. R. Sztyber, ,Skądze to zbłaźnienie świata?”. Wojciecha Dembolęckiego „, Wywód jedynowłasnego państwa świat" (studium monograficzne i edycja krytyczna), Zielona Góra 2012, s. 215-235. W szerszej perspektywie zjawisko omawia J. Reychman, Od wieży Babel do językoznawstwa porównawczego, Warszawa 1969.

48 Mowa o Wierszach Andrzeja Wiszowatego do księdza Dębołęckiego, starożytność języka polskiego nad wszystkie całego świata narody wywodzacego; tekst zabytku w: Poeci polskiego baroku..., t. 1, s. 591-593. 
wiono. Wywołało ją krótkie wtrącenie „chrząszcz, chrzest, trzmiel”49, nieomal cytat, oraz tok rozumowania Dydyńskiego, przekonującego swojego interlokutora o „wyższości polskiej mowy nad innymi” ${ }^{50}$. U Dembołęckiego kwestia ujęta dosadniej (,słów »chrząszcz«, »chrzest«, »trzpień«, »trzmiel« i tym podobnych żadna gęba niewarowna [niewyparzona - R.S.] nie wymówi" ${ }^{51}$ ), niemniej Komuda wtóruje ujęciu księdza: „słów podobnych nie wymówi żaden prostak!"52. Ciąg dalszy tej perory — „z naszą mową [...] nie może równać się ani gruby i pyszny niemiecki, ani chytry włoski, ani jadowity hiszpański" ${ }^{53}$ — stanowi najpewniej trawestację spostrzeżeń Janusza Tazbira ${ }^{54}$, powołującego się na wypisy zawarte w zbiorze Jana Czubka ${ }^{55}$. Rozmówca Jacka nad Jackami zarzuca mu, iż jego język jest „psi i lichy [...]. Zepsuty łaciną papieżnicką"56, co koresponduje z innym poglądem Wywodu, powracającym w traktacie niezmiernie często. Kluczem do rozszyfrowania tej z pozoru niedostrzegalnej zagadki jest czasownik „psuć”. W traktacie nie tylko mowa okazuje się wypaczona, lecz i... historia „wszystkie historyje tak barzo muszą być popsowane, iż [...] ledwie co w nich zostało z głosu pospolitego, czemu by rozum wierzyć pozwalał" ${ }^{57}$. Natomiast za „popsowanie słów pierwotnych"58 odpowiedzialność ponoszą inni, „poprawcy”,59 i ,garbarze słów starych"60 albo „garbarze pierwotnego języka”,61, mianowicie Grecy i łacinnicy:

Scytowie świat zrazu osadzali, tedyć osadzony gdzieżkolwiek po świecie ich naród bez wątpienia swym językiem scytyckiem abo słowieńskiem wszędy gadać musiał, póki go nie wygrzecznili na greczyznę abo nie wyłacnili na łacinę, abo jakokolwiek inaczej nie wyforemnili. Zaczym gdy którego słowa tak wyforemnionego abo raczej wypsowanego świat nie rozumie, trzeba prawdziwego jego etymonu abo wiedu imion nie gdzie indziej szukać, jeno w pierwotnem scytyckiem abo słowieńskiem języku, z którego jest wypsowane ${ }^{62}$.

49 J. Komuda, Samozwaniec..., s. 158.

50 Ibidem.

51 R. Sztyber, „Skąḋe to zbłaźnienie świata?”..., s. 306. Wszystkie cytaty z Wywodu bądź odwołania do traktatu pochodzą $\mathrm{z}$ tego wydania.

52 J. Komuda, Samozwaniec..., s. 158.

53 Ibidem.

54 Zob. J. Tazbir, Stosunek do obcych w dobie baroku, [w:] idem, Szlaki kultury polskiej, Warszawa 1986, s. 190: „żaden język nie może się równać z polskim: ani »niemiecki gruby i pyszny, ani włoski chytry, ani też hiszpański jadowity«".

55 Zob. Pisma polityczne z czasów pierwszego bezkrólewia, wyd. J. Czubek, Kraków 1906, s. 496.

56 J. Komuda, Samozwaniec..., s. 158.

57 R. Sztyber, ,, Skądże to zbłaźnienie świata?”..., s. 290.

58 Ibidem, s. 297.

59 Ibidem, s. 343.

60 Ibidem, s. 313.

61 Ibidem, s. 306, 320.

62 Ibidem, s. 305. 
Wyimek ten zahacza o istotny element koncepcji Wywodu, jego meandrów genealogicznych, scalających przeszłość Słowian, przede wszystkim Polaków, ze Scytami, przy czym rodowód tych ostatnich Dembołęcki wiąże z potomkiem rajskiej pary: Adama i Ewy. Dla księdza Wojciecha Scyta protoplasta ludu o nazwie od jego imienia wziętej to bowiem po prostu biblijny Set, młodszy brat Kaina i Abla ${ }^{63}$. W następstwie tego korelatu siedemnastowieczny historiozof gloryfikował bez umiaru ziomków, co działało ,jak haszysz na niewyrobione umysłowo tłumy szlacheckie, rozbudzając w nich megalomanię narodową, swoisty mesjanizm, przekonanie o Polsce jako kraju wybranym przez Boga"64. Kolejny etap teorii odtwarzają słowa Komudy, ponownie włożone w usta Jacka Dydyńskiego.

Jegomość Wojciech Dębołęcki [...] dzieli Scytów na dwa odłamy: mieszkających nad Wołgą Scythas Wulgares od Wołgi, a nie od wulgarności. A także Scytów osiadłych nad Odrą, Nysą i Donem, których zowie Królewskimi, zwanymi Carmatami, czyli mającymi carstwa. Z nich się wywodzi Polska z Rusią ${ }^{65}$.

Ta nobilitująca Polaków obserwacja ilustruje rozwarstwienie społeczne, ugruntowuje zarazem pozycję szlachty, władczej wobec Scytów „gminnych”, „pospolitych”, „synów ludzkich”, „synów ziemi”, chłopów66. Na przeciwległej, biegunowo skrajnej pozycji znaleźli się „synowie nieba"67, to jest herbowi, ponoć śmietanka nacji, a do nich przecież adresował swoje dywagacje ksiądz Wojciech, każdy z nich to „»nobilis«, jakoby »nebo-licz«, to jest między syny nieba policzony, [...] ślachcic"68. Nie miejsce tu, by przybliżać w pełni wizje Dembołęckiego (zwłaszcza zawoalowaną inwektywę skierowaną do wpisanych niejako w utwór jego odbiorców ${ }^{69}$ ), warto tylko uzasadnić motywacje pisarza, by dokonać papierowej aneksji dziejów scytyjskich; posłużmy się wypisem: „Scytowie w 560 lat po stworzeniu świata panowali, tedyć nie od kogo inszego mogli tak być jeszcze na on czas nazwani, jeno od tego Scyta lubo Seta"70, co dowodzi „starożytności rodzaju od Scyta lubo Seta, syna Jadamowego, jako też zacności szlachectwa od Polacha [Goga], pierwszego syna Jafetowego"71, czyli praojców Polaków. Jak wiadomo, rodowód, możliwie najodleglejszy — a Dembołęcki sięgał przecież dna czasów w rodzimej kulturze siedemnastowiecznej uchodził za najcenniejszy skarb i w $\mathrm{Sa}$ -

63 Zob. m.in. ibidem, s. 341.

64 A.F. Grabski, Zarys historii historiografii polskiej, Poznań 2000, s. 58.

65 J. Komuda, Samozwaniec..., s. 19.

66 R. Sztyber, ,Skądże to zbłaźnienie świata?”..., s. 353.

67 Ibidem.

68 Ibidem.

69 Zob. np. R. Sztyber, Do zoila nie-zoila, bo Gryzosława, „Zeszyty Naukowe Uniwersytetu Rzeszowskiego. Seria Filologiczna. Historia Literatury” 2010, z. 65; idem, Od historii (tj. „,histryjoństwa”), poprzez „,istorię” (czyli „,jako co byto” naprawdę) do... historii. Etnogenetyczne gry Dembołęckiego, [w:] Człowiek w zwierciadle przeszłości: ucieczka od historii do Historii, red. T. Ratajczak, B. Trocha, Zielona Góra 2014.

70 R. Sztyber, ,Skadże to zbłaźnienie świata?”..., s. 341.

71 Ibidem, s. 294. 
mozwańcu ów kontekst — choć zredukowany i uproszczony — znajduje absolutnie przekonujące uzasadnienie. Nie inaczej jest z traktowaniem „rycerskiego rzemięsła", potwierdzonym licznymi triumfami i hołdem największych, najmożniejszych tego świata, czego językowy ślad pozostał w określeniu kraju naszych przodków, protoplastki Rzeczypospolitej, to „Carmacyja”, ponieważ — jak objaśnia ksiądz — „wszytkie carstwa w mocy miała, jako własna ich mać, z której się poczęły”72.

Reminiscencje Wywodu we współczesnej powieści — przysłowiowe gruszki na wierzbie ${ }^{73}$, w które Komuda nie wierzy, o czym uznał za stosowne obwieścić (,nie uznaję już jakichś bzdur o herbowym pochodzeniu i rodowodzie"74) uruchamiają trwale obecne w XVII wieku pokłady myślowe, a zarazem dobitnie zaświadczają o niepohamowanej bucie braci szlachty, nieposkromionych jej ambicjach, „sarmackiej zamaszystości"75 wreszcie. I Dydyński, choć nie tylko on, mógłby być uosobieniem tej hardej, podlanej trunkiem mentalności. „Szczyt szczytów megalomanii narodowej" - celnie podsumowywał transparentne przesłanie traktatu Zbigniew Ogonowski ${ }^{76}$. Nieprzypadkowo przywołano tu nazwisko historyka filozofii, gdyż, zmierzając ku finałowi szkicu, wolno zastanowić się nad źródłem, jakie wykorzystał autor „Orłów na Kremlu”, by parafrazować bądź cytować Wywód w Samozwańcu. Dopiero co wspomniany badacz ogłosił reedycję pokaźnych i naukowo skomentowanych fragmentów traktatu w 1979 roku, lecz nie zmieścił się tam ustęp z grupą trudnych do wymówienia ojczystych rzeczowników ${ }^{77}$. W 2007 roku z kolei staraniem Kamila Jurewicza ukazało się kolejne wznowienie, które częściowo pokrywa się z wyborem Ogonowskiego ${ }^{78}$, lecz tym razem zawiera tekst, w którym Komuda znalazłby niezbędne i włączone do powieści informacje. Nie można też wykluczyć, że powieściopisarz sięgnął po jakieś inne opracowanie, chyba że brnął samodzielnie przez stary druk, „edycję niestaranną i mało czytelną, raczej odpychającą niż zachęcającą do bliższego (lub jakiegokolwiek) zapoznania się z dziełem"79. Gwoli ścisłości należy wspomnieć wznowienie Stanisława Cieślaka, także z 2007 roku, jednakże to przedruk (niezbyt udany) materiału opracowanego przez Ogonowskiego ${ }^{80}$. Pełne brzmienie

72 Ibidem, s. 281.

73 Tak określił jeden ze sposobów konstruowania argumentacji Dembołęckiego, oparty na etymologii, Julian Tuwim; zob. Pegaz dęba, czyli panopticum poetyckie, Kraków 1950, s. 330.

74 Cyt. za: A. Kobus, op. cit., s. 284.

75 J. Ziomek, Renesans, Warszawa 1995, s. 399.

76 Z. Ogonowski, Filozofia i myśl społeczna XVII wieku, cz. 1, wstęp, wyb. i oprac. Z. Ogonowski, Warszawa 1979, s. 144.

77 Zob. ibidem, s. 145-164.

78 Zob. Wojciech Dębolęcki. „Perspektywa na dojrzenie tego wywodu, która pierwej trzeba przeczytać temu, kto by miat wola rzeczom przeczyć”, wyd. i oprac. K. Jurewicz, „Terminus” 2007, z. 1 (16), s. 287-335.

${ }^{79}$ Ibidem, s. 279.

80 Zob. Wojciech Dębolęcki OFMConv, O tym, że najdawniejsze w Europie jest Królestwo Polskie, a język słowieński pierwotnym językiem świata, wyd. S. Cieślak, „Lignum Vitae” 8, 2007, s. 273-290. 
traktatu udostępniono już po powstaniu cyklu. Trudno rzecz zatem ostatecznie rozstrzygnąć, choć kilka możliwych tropów wyznaczono, być może wyjawieniem tej tajemnicy podzieli się z odbiorcą sam autor.

$* * *$

Adam Mazurkiewicz niedawno sformułował ciekawą refleksję ogólniejszej natury o najnowszym pisarstwie rodzimym i jeden z wniosków w związku z omawianymi zagadnieniami przykuwa szczególną uwagę:

rekonstrukcja wyobrażeń na temat minionych dziejów na podstawie ich fikcyjnych obrazów zawartych w tekstach kultury więcej niż o przeszłości mówi o czytelniczej teraźniejszości. Uwaga ta dotyczy zwłaszcza autorów gentium minorum, bezwiednie powielających na kartach swych utworów stereotypy, z których sieci nie potrafili się wyzwolić; to właśnie najczęściej w tych opowieściach historia staje się pretekstem do krytyki współczesności ${ }^{81}$.

Choćby w świetle tego szkicu trudno nie zgodzić się na stereotypowość ujęć autora Samozwańca, a inne studia, jak na przykład wspomniana rozprawa Tadeusza Bujnickiego, aż nadto uwypuklają wtórność pisarskiej oferty ostatnich lat. Co innego wypaczenia, o których też przyszło niestety powiedzieć; zostały one wykoncypowane na kanwie spetryfikowanych przeświadczeń, jak w przypadku Przewag. Zgoła nieprawdziwa ocena zawartości tego źródła odwołuje się do nieomal przysłowiowych wyobrażeń o lisowczykach, jedno z nich zamyka się w sformułowaniu „,co hultaj to lisowczyk" ${ }^{\prime 2}$. Zarazem i „przypisy” osiągają rangę „elementu konwencji” w prozie, lokującej wyimaginowane prezentacje przeszłości — zauważa Paweł Kaczyński ${ }^{83}$, a zjawisko ilustruje spostrzeżeniami Mariusza Czubaja: „retoryczna funkcja takich not jest analogiczna do tej, jaką pełnią przypisy w publikacjach naukowych”, mają na celu „uwiarygodnienie opisywanego świata i kompetencji autorskich" 84 . Schemat goni więc schemat, natomiast o duplikacji nie sposób mówić, ponieważ skala odwzorowań mieni się feerią wielorakich multiplikacji, skutkując pozorami demitologizowania dziejów oraz iluzją prawdy o minionym.

Wymiar teleologiczny omawianego cyklu trudno uchwycić w samym tekście, dlatego też po raz kolejny trzeba posiłkować się wypowiedzią Komudy, a ta i tym razem znajduje potwierdzenie w przytoczonej właśnie opinii Adama Mazurkiewicza, zresztą sporo tu o megalomanii, mrzonkach, ignorowaniu faktów, dyletan-

81 A. Mazurkiewicz, Strategie rekonstrukcji przeszłości we wspótczesnej polskiej literaturze popularnej (rekonesans), „Literatura i Kultura Popularna” 19, 2013, s. 27.

82 Zob. Co nowego. Zbiór anegdot polskich z r. 1650, wyd. A. Brückner, Kraków 1903, s. 78.

83 P. Kaczyński, Kryminat historyczny — próba poetyki, [w:] Literatura kryminalna. Śledztwo w sprawie gatunków, red. A. Gemra, Kraków 2014, s. 206.

84 M. Czubaj, Etnolog w Mieście Grzechu. Powieść kryminalna jako świadectwo antropologiczne, Gdańsk 2010, s. 184-185, cyt. za: P. Kaczyński, op. cit., s. 206. 
ctwie, a i bez autopromocji się nie obyło czy aspektu zwyczajnie obliczonego na komercyjny sukces.

Wyobraźcie sobie, że każda moja książka to taka mała cegiełka w murze dawnej Polski. Mało tych cegiełek jeszcze, lecz mam nadzieję, że będzie więcej. Po prostu uważam, że kultura polska, czyli szlachecka, musi zostać odbudowana, a Polacy zostać szlachtą — tak jak w XVII wieku. [...] kultura szlachecka została zniszczona [...], ale odrodzi się — zapewniam — w swojej najświetniejszej postaci ${ }^{85}$.

Lawinowo rodzą się pytania - co Komuda zamierza reanimować? Szlachtę? Kulturę szlachecką? W najświetniejszej postaci tę ostatnią? Jaką zatem? Tę odtworzoną choćby w Samozwańcu? ${ }^{86}$ A kultura polska to wyłącznie kultura szlachecka? Czy nostalgiczną tęsknotę wzbudzają: ,»parafiańska ciasnota pojęć« [...], »nietolerancja szermująca utożsamieniem [...] szlachcic-Polak-katolik, ale i ksenofobia, a także megalomania szlachecka wybujała już na przełomie XVI i XVII wieku«, [...] prowincjonalizm, fanatyzm"'?77 Trafia się i zagadka, kolejny paradoks raczej — chodzi o kluczową tu kwestię szlachectwa; przecież immanentnie wpisany jest w nią rodowód, dziedziczenie, choć, jak wspomniano, „współczesny Sarmata” genealogiczny warunek znosi, traktuje jako „bzdury”. A co z prerogatywami nobilitowanych i szczęśliwych posiadaczy papierów ostemplowanych zatwierdzeniem indygenatu? Chyba miałyby trafić w ręce wszystkich rodaków. Kto zaś byłby obowiązany do wykonywania zadań, by każdy Polak, w przebraniu odrodzonego szlachcica, mógł korzystać z przywilejów hojnie rozdzielanych przez pisarza? Postawa taka jako żywo przypomina szczodrość Dembołęckiego, który (także) zapewniając — na pokaz, na wyrost i bez umiaru — wieszczył świetlaną przyszłość państwa i nacji.

Pewna rzecz jest — pisał w zamknięciu traktatu historiozof i ,prorok” — że biały orzeł niedługo znowu przez wszystek świat skrzydła swe rozciągnie, [...], tron abo majestat świata z Polski do Syryjej przeniesie [...]. Na którem [praszczur narodu Polach, ponoć pierworodny syn Jafeta] z następcami swemi aż do skończenia świata znowu, jak przedtem Azyjej, Afryce i Europie (jeżeli nie szerzej) panować będzie ${ }^{88}$.

85 Cyt. za: A. Kobus, op. cit., s. 284-285.

86 „U Komudy - pisze A. Kobus (op. cit., s. 279-280) — warcholstwo jest nieodłączną cechą prawdziwego sarmaty, podobnie jak zapalczywość i buta, prezentowane pozytywnie i gloryfikowane przez bohaterów jego powieści. Do standardu sarmackiego obejścia w jego powieściach zaliczają się infamie i banicje, zajazdy i rapty, brak poszanowania dla prawa i umiłowanie »złotej wolności« oznaczające samowolę i prawo silniejszego (czyli bogatszego), obecne w zachowaniach zarówno antagonistów (Stanisław Stadnicki, tytułowy Diabeł Łańcucki), jak i protagonistów (Jacek Dydyński). Infamia stanowi powód do dumy, a sarmacka fantazja oznacza zazwyczaj bezmyślność i okrucieństwo".

87 B. Stuchlik-Surowiak, Sarmatyzm — dzieje jednego pojęcia, „Perspektywy Kultury” 2012, nr 6, s. 31-32.

88 R. Sztyber, ,Skądże to zbłaźnienie świata?”..., s. 417. 
To między innymi z powodu takich orzeczeń, nadto podpieranych perykopami biblijnymi, na głowę księdza Wojciecha posypały się gromy, a jego dzieło, przypomnijmy, otrzymało jednoznaczną etykietę — ,głupstwo”, o czym wspomniał Komuda.

Wolno domniemywać, że gdyby dzisiejszemu twórcy pozostawiono możliwość wyboru gatunku powieściowego (jaki uprawia) w zaproponowanej przez Mazurkiewicza typologii ${ }^{89}$, Komuda swoje dokonania z pewnością pragnąłby zaliczyć do zbioru tekstów z ambicjami do „demitologizacji obrazu przeszłości”, niemniej kwalifikację tę przekreślają rozpoznania pomieszczone w wielu przywoływanych tu szczegółowych analizach (komparatystycznych), a także treść lwiej części tego szkicu. Drugą kategorię opatrzył badacz szyldem ,apologia przeszłości”, lecz — jeśli termin ten traktować literalnie - cykl Komudy mógłby ewentualnie znaleźć się w tej grupie tekstów, a takie jego sklasyfikowanie zyskałoby akceptację chyba wyłącznie u „współczesnych Sarmatów” (z uwagi na ukazany w Samozwańcu obraz dawnego wczoraj). Trzecią i ostatnią grupę (umożliwiającą „eksperyment myślowy”) pomijamy, ponieważ „Orły na Kremlu” nie spełniają jej kryteriów - nie przynoszą ,alternatywnego biegu dziejów”. Sprawę klarują obserwacje Bujnickiego: „ostatecznie mamy rozwiązania zgodne z rzeczywistym przebiegiem zdarzeń dziejowych", to historia zdobiona domysłami w następstwie wypełniania „miejsc "pustych « bądź niejasnych i tajemniczych. W te miejsca wkłada Komuda własne hipotezy, które w jego powieściach są traktowane jak fakty zachodzące rzeczywiście" 90 . Albo raczej winny tak wypadać, fakty bowiem „przypisowe” niekiedy mijają się z prawdą, gdyż zwyczajnie przynoszą dane bałamutne. I, co symptomatyczne, w rekonesansowej panoramie Mazurkiewicza nie pada nazwisko poczytnego, popularnego pisarza, a wiele wskazuje, że niekoniecznie mimowolnie jesteśmy świadkami procesu demaskowania epigońskich praktyk (sprzecznych z manifestowanymi deklaracjami), często niestarannych, mało rzetelnych, przez co umiarkowanie wiarygodnych i niezbyt oryginalnych, choć uzasadnionych handlowo czy marketingowo dzięki atrakcyjności opakowania. Zatem i kontekst pozaliteracki, aspekty merkantylne bezsprzecznie należy uwzględniać w tego rodzaju ocenach, gdyż tylko one usprawiedliwiają podejmowane prawie jedynie literacko ryzyko.

89 Zob. A. Mazurkiewicz, op. cit., s. 13-27.

90 T. Bujnicki, op. cit., s. 324. 


\section{Bibliografia}

Bartoszewicz J., Ksiądz Wojciech z Konojad Dembołęcki, [w:] idem, Studia historyczne i literackie, wyd. K. Bartoszewicz, t. 2, nakładem K. Bartoszewicza, drukiem F.K. Pobudkiewicza w dzierżawie A. Koziańskiego, skład główny w Warszawie w księgarni Gebethnera i Wolffa; w Krakowie w księgarni F.K. Pobudkiewicza, Kraków 1881.

Bauer M., Nad „Przewagami elearów polskich” Wojciecha Dembolęckiego. O apologetycznym pamiętniku z walk lisowczyków w krajach monarchii habsburskiej podczas pierwszych lat wojny trzydziestoletniej, „Napis” 11, 2005, s. 53-64.

Bauer M., Z dziejów batalistyki polskiej. Studia nad pamiętnikami wojennymi z XVII w., Wydawnictwo Collegium Columbinum, Kraków 2007.

Bibliografia literatury polskiej „Nowy Korbut”, t. 2. Piśmiennictwo staropolskie (hasta osobowe $A-M)$, oprac. zespół pod kier. R. Pollaka, Państwowy Instytut Wydawniczy, Warszawa 1964.

Bujnicki T., Jacek Komuda w kręgu aluzji sienkiewiczowskich, [w:] Pejzaże humanistyczne. Księga jubileuszowa Profesorowi Bolestawowi Faronowi poświęcona, red. A. Ogonowska, Impuls, Kraków 2017, s. 319-332.

Bystroń J.S., Megalomania narodowa, [w:] Jan Stanisław Bystroń. Tematy, które mi odradzano, oprac. i wstęp L. Stomma, Państwowy Instytut Wydawniczy, Warszawa 1980.

Co nowego. Zbiór anegdot polskich z r. 1650, wyd. A. Brückner, Wydawnictwa Akademii Umiejętności w Krakowie, Księgarnia Spółki Wydawniczej Polskiej, Kraków 1903.

Czubaj M., Etnolog w Mieście Grzechu. Powieść kryminalna jako świadectwo antropologiczne, Oficynka, Gdańsk 2010.

Darowski Weryha A., Samuel Łaszcz. Strażnik koronny, Drukarnia Uniwersytecka, Kijów 1865.

Dzieduszycki M., Krótki rys dziejów i spraw lisowczyków, t. 1-2, Zakład Narodowy im. Ossolińskich, Lwów 1843-1844.

Ekes J., Złota demokracja, Ośrodek Myśli Politycznej, Warszawa 2010.

Gloger Z., Encyklopedia staropolska ilustrowana, t. 1, druk P. Laskauera i W Babickiego, Warszawa 1900.

Grabski A.F., Zarys historii historiografii polskiej, Wydawnictwo Poznańskie, Poznań 2000.

Józef Barttomiej Zimorowic. Utwory młodzieńcze, oprac. R. Krzywy, Wydawnictwo Naukowe Sub Lupa, Warszawa 2016.

Jurewicz K., Wojciech Dębolęcki i jego „,Wywód...”, „Terminus” 2007, z. 1 (16), s. 279-285.

Kaczyński P., Kryminat historyczny - próba poetyki, [w:] Literatura kryminalna. Śledztwo w sprawie gatunków, red. A. Gemra, Wydawnictwo EMG, Kraków 2014, s. 191-209.

Kliszcz A., Sarmacki zwrot kulturowy?, „Perspektywy Kultury” 2012, nr 6, s. 55-66.

Kobus A., Sarmatotopie. Formacja sarmacka w twórczości Jacka Komudy, „Teksty Drugie” 2015, nr 1, s. 273-293.

Kochańska M., Ksiądz Wojciech Dembołęcki z Konojad, „Prace Literackie” 1, 1956, seria A, nr 2, s. 101-143.

Komuda J., Opowieści z Dzikich Pól, Wydawnictwo Alfa-Wero, Warszawa 1999.

Komuda J., Samozwaniec, il. H. Czajkowski, t. 3, Fabryka Słów, Lublin 2013.

Królikowski B., Szable nie rdzewiały, czyli przewagi lisowczyków nad Turkiem srogim pod Cecora $i$ Chocimiem czynione, Wydawnictwo Ministerstwa Obrony Narodowej, Warszawa 1983.

Mazurkiewicz A., Strategie rekonstrukcji przeszłości we współczesnej polskiej literaturze popularnej (rekonesans), „Literatura i Kultura Popularna” 19, 2013, s. 13-28.

Narolska A., Upraszczanie Hugo. „,Katedra Marii Panny w Paryżu” w „Diable w kamieniu” Jacka Komudy, [w druku].

Ogonowski Z., Filozofia i myśl społeczna XVII wieku, cz. 1, wstęp, wyb. i oprac. Z. Ogonowski, Wydawnictwo Naukowe PWN, Warszawa 1979.

Literatura i Kultura Popularna 26, 2020

(C) for this edition by CNS 
Pisma polityczne z czasów pierwszego bezkrólewia, wyd. J. Czubek, nakładem Akademii Umiejętności w Drukarni Uniwersytetu Jagiellońskiego, Kraków 1906.

Podhorodecki L., Wazowie w Polsce, Ludowa Spółdzielnia Wydawnicza, Warszawa 1985.

Poeci polskiego baroku, wstęp, wyb. i oprac. J. Sokołowska, K. Żukowska, t. 1, Państwowy Instytut Wydawniczy, Warszawa 1977.

Reychman J., Od wieży Babel do językoznawstwa porównawczego, Wiedza Powszechna, Warszawa 1969.

Sabowski W., Obiadowa godzina, „Przegląd Tygodniowy Życia Społecznego, Literatury i Sztuk Pięknych" 1866, nr 12-15.

Sienkiewicz H., Ogniem i mieczem. Powieść z lat dawnych, t. 2, Wydawnictwo Zakładu Narodowego im. Ossolińskich, Lwów 1931.

Stuchlik-Surowiak B., Sarmatyzm - dzieje jednego pojęcia, „Perspektywy Kultury” 2012, nr 6, s. 21-38.

Szagun D., Przekorne nawiazania do Sienkiewiczowskiego wzorca powieści historycznej w „Bohunie” Jacka Komudy, „Acta Universitatis Lodziensis. Folia Linguistica” 2015, nr 49, s. 81-92.

Sztyber R., Do zoila nie-zoila, bo Gryzosława, „Zeszyty Naukowe Uniwersytetu Rzeszowskiego. Seria Filologiczna. Historia Literatury" 2010, z. 65, s. 42-61.

Sztyber R., Od historii (tj. „histryjoństwa”), poprzez „istorię” (czyli ,jako co byto” naprawdę) do... historii. Etnogenetyczne gry Dembołęckiego, [w:] Człowiek w zwierciadle przeszłości: ucieczka od historii do Historii, red. T. Ratajczak, B. Trocha, Oficyna Wydawnicza Uniwersytetu Zielonogórskiego, Zielona Góra 2014, s. 325-347.

Sztyber R., „Skądże to zbłaźnienie świata?”. Wojciecha Dembołęckiego ,, Wywód jedynowłasnego państwa świat" (studium monograficzne i edycja krytyczna), Oficyna Wydawnicza Uniwersytetu Zielonogórskiego, Zielona Góra 2012.

Sztyber R., Wstęp, [w:] W. Dembołęcki, Przewagi elearów polskich, wstęp i oprac. R. Sztyber, Wydawnictwo Adam Marszałek, Torun 2005.

Tazbir J., Stosunek do obcych w dobie baroku, [w:] idem, Szlaki kultury polskiej, Państwowy Instytut Wydawniczy, Państwowy Instytut Wydawniczy, Warszawa 1986, s. 186-202.

Tuwim J., Pegaz dęba, czyli panopticum poetyckie, Spółdzielnia Wydawniczo-Oświatowa „Czytelnik", Kraków 1950.

Wisner H., Lisowczycy, Wydawnictwo Bellona-Oficyna Wydawnicza Rytm, Warszawa 1995.

Wisner H., Władysław IV Waza, Zakład Narodowy im. Ossolińskich, Wrocław 2009.

Wojciech Dębotęcki OFMConv, O tym, że najdawniejsze w Europie jest Królestwo Polskie, a język stowieński pierwotnym językiem świata, wyd. S. Cieślak, „Lignum Vitae” 8, 2007, s. 273-294.

Wojciech Dębolęcki. „Perspektywa na dojrzenie tego wywodu, która pierwej trzeba przeczytać temu, kto by miat wola rzeczom przeczyć”, wyd. i oprac. K. Jurewicz, „Terminus” 2007, z. 1 (16), s. $287-335$.

Ziomek J., Renesans, Wydawnictwo Naukowe PWN, Warszawa 1995.

Literatura i Kultura Popularna 26, 2020

(C) for this edition by CNS 


\title{
Towards national megalomania on the basis of Jacek Komuda's tetralogy Samozwaniec [False Dmitry] (a glossary and a few remarks in the margins of the novels)
}

\begin{abstract}
Summary
The sketch is an attempt to analyse chosen details noticed in Jacek Komuda's novel cycle entitled Orty na Kremlu [Eagles at the Moscow Kremlin]. The discussed matters concern particularly two fragments of dialogues enriched with clear allusions to Wojciech Dembołęcki's quite widely known treatise Wywód jedynowłasnego państwa świata [Treatise on the only country in the world] and an endnote - delivered by the author himself - on the aforementioned book (published in 1633) with additions: some brief characteristics of Dembołęcki and his output. As it appears, any observation or reference to the works of the Polish monk (who died in the mid-seventeenth century) is not extracted from archives, old prints, as Komuda assures us (describing his course of work in his interviews). They rather come both from articles or excerpts found in research books released by scholars. Besides, Komuda in his declared approach to literary work does intend to differentiate significantly from Henryk Sienkiewicz's masterpiece (Trylogia [The Trilogy]), however many writings of Komuda deny such an idea, which has been proven thorough studies. Nevertheless, the Wywód's quotations and its transparent paraphrases seem to be valuable in contemporary historical prose, for thanks to them the reader may be acquainted with people's (especially Polish noblemen's) mentality at the beginning of the seventeenth century. Unfortunately, the notes bring some meaningful misunderstandings revealing Komuda's ignorance, because one may fail in correctly recognising the text's main message (Przewagi elearów polskich [The exploits of elears]) or the origin of rhymes cited by the novelist. The sketch closes with a few thoughts concentrated on a possible Samozwaniec qualification within Adam Mazurkiewicz's typology proposal of historical prose published nowadays.
\end{abstract}

